\title{
WestVirginiaUniversity
}

THE RESEARCH REPOSITORY @ WVU

Graduate Theses, Dissertations, and Problem Reports

2015

\section{"Man of the House": A Turning Point That Leads to Criminal Behavior?}

\author{
Delia A. Trickett
}

Follow this and additional works at: https://researchrepository.wvu.edu/etd

\section{Recommended Citation}

Trickett, Delia A., "'Man of the House": A Turning Point That Leads to Criminal Behavior?" (2015). Graduate Theses, Dissertations, and Problem Reports. 6832.

https://researchrepository.wvu.edu/etd/6832

This Thesis is protected by copyright and/or related rights. It has been brought to you by the The Research Repository @ WVU with permission from the rights-holder(s). You are free to use this Thesis in any way that is permitted by the copyright and related rights legislation that applies to your use. For other uses you must obtain permission from the rights-holder(s) directly, unless additional rights are indicated by a Creative Commons license in the record and/ or on the work itself. This Thesis has been accepted for inclusion in WVU Graduate Theses, Dissertations, and Problem Reports collection by an authorized administrator of The Research Repository @ WVU. For more information, please contact researchrepository@mail.wvu.edu. 


\title{
"Man of the House": A Turning Point That Leads
}

to Criminal Behavior?

\author{
Delia A. Trickett \\ Thesis Submitted to the \\ Eberly College of Arts and Sciences \\ at West Virginia University \\ in partial fulfillment of the requirements \\ for the degree of
Master of Arts
in
Sociology
Corey Colyer, Ph.D., Chair
Jesse Wozniak, Ph.D
Rachel Stein, Ph.D \\ Department of Sociology \\ Morgantown, West Virginia \\ 2015
}

Keywords: juvenile delinquency, birth order, household structure, life-course theory Copyright 2015, Delia A. Trickett 


\section{ABSTRACT \\ "Man of the House": A Turning Point That Leads to Criminal Behavior? By Delia A. Trickett}

This research study seeks to formally test a relationship between household structure, birth order and juvenile delinquency that was suggested as an onset to criminal behavior by men incarcerated in a maximum security facility. The focus of this study is on first born males due to the retrospective narratives given by the incarcerated men that being a first born male who has either lost a father-or father figure due to death, divorce and/or prison have felt a sense of responsibility as the "man of house" to be able to provide family stability which can include care of other siblings, maintaining the home through housework and in some cases maintaining the family financially. This study tests whether (1) delinquent acts for monetary gain increases if the adolescent is a first born male and (2) delinquency increases if the juvenile first born male is living in a female headed household. I use Sampson and Laub's (1993) life course theory and the NLSY79 to test the hypothesis. Tobit regression models suggests there is no relationship in increased delinquency for monetary gain for first born males and first born males living in a single female headed household. 


\section{TABLE OF CONTENTS}

I. Introduction................................................................

II. Literature Review

a. Life-Course Theory................................................4

b. Family Structure................................................10

c. Birth Order.......................................................11

III. Methods and Data.....................................................13

IV. $\quad$ Findings.................................................................21

V. Discussion..............................................................24

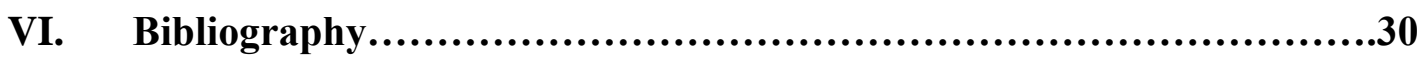




\section{"Man Of The House": A Turning Point That Leads to Criminal Behavior?}

\section{Introduction}

During my last semester as an undergraduate I participated in a class called the "InsideOut Prison Exchange Program" with a focus on re-entry and reintegration (into society postincarceration). The class was held in a men's maximum correctional facility and we met once a week for three hours throughout a sixteen week semester. The class was structured to have up to 32 students which consisted of 16 inside students (incarcerated individuals) and 16 outside students (university students) and one certified Inside-Out instructor (professor). The purpose of the class was to gain knowledge through dialogue of the correctional system and re-entry into society after incarceration through theoretical and practical experiences.

The Inside-Out program originated out of Temple University, the founder and director created a program where two of the largest institutions (prisons and colleges/universities) could collaborate in a unique learning experience. The class readings examined the correctional system (societal purpose of prisons), the individual's involvement in the criminal justice system, and the community's role (such as neighborhoods and peers) in pre and post incarceration. The class facilitated open dialogue on the readings. Group discussions allowed both the inside students and outside students to speak on personal experiences whether it be on the criminal justice system, their environment growing up or other factors that may pertain to the readings. Assigned readings included criminological theories such as strain theory, labeling theory, social disorganization theory, social learning theory and rational choice theory. During small group discussions all students were given an opportunity to apply these theories as it related to their 
lives. The incarcerated men in my group discussed how their household structure and their environment played a role in their criminal behaviors.

Through these conversations I recall one man who said that his father was murdered and as a result his mother became the sole provider for their family. He was the oldest child and had younger brothers and sisters. His mother told him he would have to be the "man of the house" since he was the oldest child and their father was no longer around. He claimed that he began selling drugs and committing crimes in order to help his mother financially. He later dropped out of high school because it (school) got in the way of him being able to financially assist his mother and family.

Throughout the semester other inside students offered retrospective accounts of their early childhood experiences. Another inside student spoke on growing up in a crime ridden area of southern California while living with his mother and little brother. His father was in and out of their lives. He remembered a time when his mother begged their landlord for more time to pay rent (she was behind on the rent payment), and recalled seeing her cry. He, as a child, wanted to find a way get his mother the money they needed for housing. He went to neighbors and asked to do chores around their house in order earn money to help his mother financially. Unfortunately, what little money he was able to get wasn't enough to help his mother pay the rent so he resorted to committing theft and armed robbery in order to help his mother pay for rent. He believed that he needed to help his mother so that she wouldn't have to beg again.

Throughout the discussions we had during class, many of the inside students reflected on living in a single female headed household. Their reflections included how their father was no longer around due to separation or divorce, incarceration or death. Some of the men, including the two previously discussed, are first born sons and expressed that they felt a responsibility to 
help their families financially. They spoke of committing criminal activities in order to provide food, shelter and money for their families. Some felt they had to shoplift, sell drugs, and commit robbery/burglaries at a young age because they could not get legitimate work due to their age and inexperience. As the men reflected on their lives and the onset of their criminal behavior, I noticed a pattern: many were first born males growing up in a single parent female headed household and committed crimes due to their sense of responsibility because they saw themselves as having to be the "man of the house". This observation suggested a hypothesis. Is there a relationship between household structure, birth order, and juvenile delinquency? This thesis sets out to test that hypothesis.

This study poses a question: are first born juvenile males living in a single parent female headed household more prone to commit delinquent acts for monetary gain than other children? This question seeks to formally test the relationship suggested by the inside student's narratives, that they robbed and stole to satisfy their responsibilities "as the man of the house". Based on the retrospective oral histories of the incarcerated men described above; I test whether: (1) delinquent acts for monetary gain increases if the adolescent is a first born male and (2) delinquency increases if the juvenile first born male is living in a female headed household.

Studies of juvenile delinquency often operationalize delinquency broadly including status offenses (truancy, running away, etc.), official crime data (through police and court records), and information pertaining to school discipline. This study restricts the definition of delinquency to only include property offenses. I hypothesize that first born males living in a single female headed households will be more likely to commit property offenses than other children. Disruption to the family structure, through divorce, incarceration, and death, may leave the adolescent feeling as though they have to become the 'man of the house' in order to help their 
mother. When children feel the responsibility of maintaining the house through 'work' or other financial means they may resort to illegal activities. This thesis seeks to test that hypothesis.

I employ a nationally representative sample of fourteen to eighteen year olds from the National Longitudinal Survey of Youth 1979 (NLSY79). My theoretical framework is based on Sampson and Laubs (1993) life-course perspective which looks at how transition(s) and turning points change trajectories of life paths. Previous studies demonstrate a linkage between juvenile delinquency and family structure (e.g. Mitchell 2013; Johnson and Mollborn 2009; Sullivan 1989; Antecol and Bedard 2007). I add to these findings by examining life course turning points, like the ones that are described by the incarcerated men. We can see how adaptations to short term events have a lasting impact on life. This study attempts to measure early childhood/adolescence turning points and determine if there is an increase in delinquent acts for monetary gain based on the household structure and birth order. By recognizing the effects of turning points, we can intervene and change the life course trajectory of these young men as well as other young men that are in similar situations.

\section{Literature Review}

\section{$\underline{\text { Life-Course }}$}

Criminology theories such as Merton's theory of Anomie (Merton, 1957), differential association theory (Sutherland, 1939), social disorganization theory (Shaw and McKay, 1942) and social bond theory (Hirschi, 1969) look at particular stages or moments in life to pinpoint either the persistence and desistance of criminal behavior. Life course theory is an inclusive theory because it allows one to look at every stage in life to evaluate how and why an individual(s) began, persisted and desisted criminal behavior. According to criminologists, 
juvenile crime and deviance is a predictor of adult criminality (Laub, Sampson and Sweeten 2006). Sampson and Laub used life course theory to better understand the onset of criminal behavior. Life course theory focuses on relationships and status transitions in life from birth to death. Previous studies suggest that the life course theory should include a focus on examining and predicting influential adolescent turning points rather than mapping out the delinquent and criminal trajectories that most researchers have done when working on the life course theory (Bersani and Chappie, 2007).

In Crime in The Making, Pathways and Turning Points Through Life, Sampson and Laub (1993) argued that previous work on the onset of crime focused primarily on formal mechanisms of social control. They broadened the inquiry to include informal mechanisms of social control. Institutions facilitating informal mechanisms of social control include the "family, school, peer groups and the juvenile justice system" (page 18). Studying the home environment, school ties and peer ties allowed Sampson and Laub to measure the child's bonds and/or attachments as well as how these bonds and attachments influence the likelihood of the child committing delinquent acts.

To get a better perspective on crime and why one commits criminal activities Sampson and Laub used data from Unraveling Juvenile Delinquency, a study conducted by Sheldon and Eleanor Glueck at Harvard University over an eighteen year period beginning in the fall of 1939. The Glueck study looked into the lives of a total of 1000 boys (500 delinquent, 500 nondelinquents) from the Massachusetts area. They drew data from a variety of sources (the children, their parents, and their teachers). Interviews were conducted for the purpose of personality and behavioral characteristics to add to reports from social workers, court documents, school and the home environment. The Gluecks were able to conduct interviews during multiple 
stages of the men's lives (wave I- ages 17-25, wave II- ages 25-32 and wave III- ages 32-45). The control group (non-delinquents) were similar to delinquents on structural factors such as their neighborhood, age, race/ethnicity and intelligence. By gathering longitudinal data, the Gluecks were able to study career criminals.

Sampson and Laub reanalyzed more than 15,000 computer punch cards discovered in the Glueck's study archives using modern computers and contemporary quantitative analysis procedures. They captured approximately 2,500 different variables from the cards including many indicators of life course transitions. Sampson and Laub used these data to examine the role played by informal social bonds in mediating delinquency. These are those bonds created through relationships forged at work, school, home and elsewhere in the child's environment. A child's antisocial behavior could be attributed to weak social bonds leading to worrisome adult behaviors. In addition to measures of antisocial behavior Sampson and Laub used measures on household crowding, family disruption, family size, social economic status, residential mobility, mother and father employment and father and mother criminality/drinking as variables to capture the subjects' attachment to school, peers and siblings which will determine the variation of the onset of delinquency.

Results of the regression models show that delinquency increases when youth bonds are weakened through family or school (Sampson and Laub, 1993). Sampson and Laub also found that supervision by the mother had the largest mediating effect on the child's attachment to delinquent peers. This reinforced Hirschi's Bond theory (1969) which treats a juvenile's bond to family and society as a predictor of delinquency. Sampson and Laub built on Hirshi's bond theory by examining relationships between bonds and turning points that can change an individual's pathway. 
Sampson and Laub developed a theory of "turning points" that follow a person's trajectories and transitions in life. These trajectories and transitions are vital concepts of the life course theory because it is a major factor in how one's life can change for better or worse depending on the situation. Sampson and Laub defined a trajectory as a direct life path. The trajectory is a long term pattern such as marriage, parenthood or criminal behavior. Societal norms say that the predicted life path is to attend school through high school, continue through higher education or obtain a job, followed by getting married, having children, growing old and retiring. However, some communities or subcultures develop their own norms which include criminal behavior, gangs and violence. Growing up in an area or neighborhood in which finishing or continuing education is not the 'way of life' changes the 'predicted' life path for affected residents.

Analyzing wave II and III from the Glueck data allowed Sampson and Laub to compare the age of onset and social bonds. Adult social bonds (formal and informal) are a turning point which can change the life course from criminal behavior to non-criminal behavior. Sampson and Laub argue that investing in social capital (gain in social bond through relationships and institutions such as work) inhibits the individual from committing crimes. An individual can be married and/or employed and continue to commit crimes or desist, but it is whether the individual had positive bonds within a relationship whether it be work or family, that allows them to commit crimes.

As previously stated a trajectory is a long term path marked by transitions. A transition is an event or gateway that changes the life path. Examples include completing school, obtaining a first job, getting arrested, being sent to reform school, etc. One can examine the effects of various transitions on a predicted trajectory. Consider a predicted trajectory such as marriage, 
parenthood and a career and a transition can be a job promotion which will positively change the comfort of living and possibly the children's education within that family. But if we look at the same scenario with a negative transition such as a job loss or dissolution of marriage the family's trajectory has now changed negatively. Job loss can permanently or temporarily change where the family resides, what type of education their child will receive and many other trickled down effects due to loss of wages. When we look at children/adolescents the transitions that occur within the family structure can have a lasting impact. Parents must change their living arrangements due to changes in income. These decisions may not be what the child wants but in order to adequately provide for their children parents may live in a more inexpensive area. Since children are not able to make their own decisions with whom and where to live when there is dissolution of marriage, these transitions can mark a turning point in the child's life. Therefore, multiple transitions can lead to changes in the direct life path.

Life course focuses on the length, timing and sequence of life events and the results in later development (Sampson and Laub, 1993). This can be seen like a pinball machine where the goal is to get the ball to shoot into a hole (trajectory) but there are many flippers that redirect the ball to shoot in different directions (transitions) that eventually allow the ball to go into the hole. The combination of trajectories and transitions are turning points. A study by K. Mitchell (2013) suggests that studying family structure trajectories are more in line with the life course perspective than individual transitions. Although this is true, an analysis of individual transitions allows an in depth look at why trajectories change over time.

Sampson and Laub used waves I and II from the Glueck data for the control group (nondelinquents) to measure crime/deviance as well as looking at the causes of 'late onset' criminality. Their results were as expected; the control group had a lower likelihood than the 
delinquents in committing crime/deviance. But it did show that those in the control group at ages 17-25 who have low job stability were four times more likely to be arrested and by age $25-32$, are more than six times more likely to use alcohol excessively than those who have high job stability, marital attachments and aspirations in their education and/or occupation.

The study Sampson and Laub conducted showed that having a stable job as well as being married creates a social bond in which the tendency to commit crime is reduced. The study also concluded that a main turning point in a person's life is employment. Employment can be either long term or short term in duration. Employment is one of the main environments in which we interact with others in society. Work directly correlates to whether or not individuals persist or desist in criminal activity. Work is important because it is a place where one builds social bonds and interacts with others and thus conforms to social norms. According to Sampson and Laub (2003) stable employment can serve as a social control function that provides a structured routine as well as "an identity and a sense of accomplishment" (page 139). These strong social bonds can be very important, especially early in life.

In terms of societal norms, "by allocating resources to younger at risk populations, society reaps the multiplier effects of a lifetime of industrious conformity" (Uggen, 2000). In other words, if young people are given opportunities within the work system, then they will continue to benefit themselves and thus benefit society as a whole. Although previous studies show that employment can create strong social bonds, employment itself is not necessarily a deterrent to criminal activities. In cases where the individuals are too young to work due to age restrictions on labor laws, criminal activities arise as "employment" opportunities to underage individuals. This new "work" environment can create positive social bonds with the "employer" and the "employees" as the underage individual has been afforded an opportunity to gain social 
capital. The types of work can include selling drugs, stealing cars and other criminal activities.

Due to the criminal activities that underage individuals become part of, these social bonds are not accepted by society. These informal social bonds are what Sampson and Laub developed in their theory as an explanation of crime and deviance over the life course.

\section{$\underline{\text { Family Structure }}$}

Family structure in the United States is ever changing and evolving. There can be many turning points for a child linked to family structure which includes: the loss of a parent through divorce/separation or death, loss of income, moving to a new area, meeting new peers at school, etc. These turning points can be very hard for a child to deal with. Many studies look at family structure to see how change in family structure affects the child. According to Vespa (2013) in the U.S. Census Bureau report for 2012, 66\% of households were dual parent households which has declined from $81 \%$ in $1970,27 \%$ of families were living in a mother only household while father only households consisted of $5 \%$ of the population. The report also shows that for father only households $44 \%$ of household change was due to divorce compared to mother only household in which $47 \%$ are never married mothers.

Family structure is an area in a child's life where they have no control and this transition can have long lasting impacts on their life course (Langenkamp, 2008). Presence of the biological father in the household decreases the likelihood of adolescent criminal convictions. Adolescents who never had their father present were found to be more likely to engage in deviant behaviors than those with fathers always present. (Antecol and Bedard, 2007, Thomas et al.,1996). A study by Harper and McLanahan (2004) hypothesized that children with absent fathers (born to single mothers) have a higher chance of incarceration. The hypothesis is centered 
on Hirschi's bond theory and how not having and attachment or bond with a father increases delinquency and subsequently incarceration. The study did find that youths living in households without a father had higher odds of incarceration.

Divorce is another factor that can affect a child. "Divorce makes children 'grow up a little faster"' (Johnson, 2009). Although change in family structure can be considered a single change, there is more recognition now that for children, the change is one of several transitions. The new family structure and living conditions that follow divorce, like a new parent, new neighborhood, and different economic conditions etc., are all things a child must cope with in addition to the divorce. Harper (2004) found that "children living in stepparent households faced incarceration odds almost three times as high as those in mother-father families, and significantly higher than those in single-parent households" (page 390). Harper's (2004) discussion on step families sheds light into life course theory (Sampson and Laub, 1993) and having positive social capital in formal institutions such as school. The study linked incarceration odds and residential moves, which is associated with step-families (page 388). Looking at changes in relationships with parents and their new partners as well as how often those changes occur could have an effect on the child which can change the predicted life path.

\section{Birth Order}

Studies have looked at how birth order affects IQ, social behavior, criminality or delinquency and other psychological aspects. While research on birth order has been old and limited to the effects within siblings, I believe that birth order plays a part in delinquency as suggested by the incarcerated men even if it is true to a subset of offenders. Some of the reflections from the inside students suggest that by being the first born male without a father or 
father figure they felt a sense of responsibility to be "the man of the house". The most recent study on birth order and delinquency by Cundiff (2013) examines delinquency as a form of competition within siblings seeking parental attention. The study did not find any statistical significance between middle-born children and last born children, nor could they find evidence that first borns are less likely to commit delinquency than their younger siblings. This study looked at delinquency with intact families, which adds to a lack of research in delinquency, birth order and family structure.

A study by Rowe et al. (1992) examined the relationship between birth order and delinquency in varying family sizes. The study was conducted on family sizes ranging from two to four children. The study looked at the first child and the age difference (space) between the second child compared to the first child, the third child compared to the first child and the fourth child compared to the first child. The sibling's sex was also included in the study to determine if environmental unshared influences had an effect on delinquency. Their results showed that siblings, specifically brothers that are closer in the birth order have a higher tendency to engage in delinquency than siblings with greater space (first born compared to third or fourth born children). Although this study looked at the siblings and age differences, their study did not include family structure in determining whether sibling delinquency and birth order was greater in different households such as single headed household or dual headed households.

Another study by Warren, J. (1966) looked at birth order and social behavior. He argued that studies that contain birth order as a variable include only born children as being the eldest born child as well. But he made the argument that one study found that children without siblings are more like the youngest child than the oldest. His study found that first-borns of both gender "attend college at a higher number than later born" (children). Another study on birth order and 
delinquency by Rahav (1980) referenced two studies, one from Levy (1931) which concluded that more acts of delinquency are committed by only children than by children with siblings. The second study by Wile and Noetzel (1931) stated that eldest children were more delinquent. While the studies are dated, there are still debates on whether to include only children with oldest child or only children with youngest and lastly to remove only children from samples.

\section{Methods}

$\underline{\text { Data }}$

In the 1960's social scientists and policymakers partnered with the designers of the National Longitudinal Survey (NLS) because they believed that in order overcome lifelong poverty, individuals need effective job training and education. Due to government initiatives such as the War on Poverty and the office of Equal Opportunity it became imperative for researchers to get a survey of youth making transitions into adulthood as well as information on labor-force behavior in the United States (Chase-Lansdale et alt, 1991). The National Longitudinal Survey (NLS) was funded by the U.S. Department of Labor.

In 1979 the NLS created the NLSY (National Longitudinal Survey of Youth) which consisted of individuals born between January 1, 1957 and December 31, 1964. Statistical information in the NLS website (NLSinfo.org) shows that the respondent's ages ranged between 14 and 22 at the time of the first interview. A total of 12,686 individuals were interviewed in 1979. This consisted of 6,403 males and 6,283 females; 7,510 non-black/non-Hispanic, 3,173 black and 2,002 Hispanic or Latino. In order to get a representative sample of the entire population of youths between the age of 14 and 21 that live in the United States on January 1, 1979 the survey consisted of three independent probability samples. The samples are (1) a cross- 
sectional sample of 6,111 to represent non-institutionalized civilian young people, (2) a supplemental sample of 5,295 representing Hispanic or Latino, Black and economically disadvantaged whites and (3) a military sample of 1,280 that represents military service as of September 30, 1978 and that were born between January 1, 1957 and December 31, 1961. Information that was obtained from the survey included:

- Labor market behavior

- Educational experiences (high school, college, training)

- Family background (including data collected from parent in round 1)

- Armed Services Vocational Aptitude Battery (measures knowledge and skills including reading and mathematics)

- High school information received from respondents' schools and from respondents' school transcripts

- Government program participation

- Family life (marital status, fertility, and child care)

- Health issues

- Assets and income

What makes the NLSY79 survey unique is that of the 8,770 households that were surveyed 5,908 respondents were single respondents. The remaining 2,862 households had multiple respondents which included multiple siblings (2-6 siblings for a total of 5,863 respondents), spouse and other members of the household (915 respondents) (NLSYinfo.org). The survey allowed for a unique look into household demographics that included maternal employment, child-care, divorce and father absence, multigenerational parenting and poverty.

In 1980 a section on delinquency, arrest data and criminal activities that were committed during the previous twelve months were included in the survey. Categories for delinquency and criminal activities includes: skipping school, alcohol/marijuana use, vandalism, shoplifting, drug dealing, robbery, assault and gambling. Respondents that were age 17 and under were asked status offense questions such as running away from home, truancy and drinking. Answers from respondents on delinquency and criminal activities ranged from never (0) to more than 50 times 
within the previous twelve months. Categories for the criminal justice questions consisted of what type of contact with police the respondent had, such as what type of arrest, whether or not they were convicted and whether or not they were housed in a youth or adult correctional facility.

This thesis builds on Harper's (2004) examination of factors leading to incarceration, specifically father's absenteeism. My study invokes several of the ideas and concepts developed in Harper's work. However, I have introduced birth-order as an additional variable. The Harper study (2004) developed a delinquency scale to test whether father absence increases the odds for youth incarceration. The study also included the use of the NLSY79 to determine if fathers' absence affects male youth incarceration. The researchers used life course as their theoretical framework.

Using the NLSY for this study allowed Harper (2004) to construct an age based event history analysis on fathers' absenteeism on delinquency that leads to incarceration. In the study the researchers were able to construct a sequence of events in which the father was with the adolescent and when, whether the adolescent lived with their mother or with whom the adolescent was living with at age 14 to 16 . Living in a dual parent, single-parent (male/female) household, biological mother with step-father, biological father living with step-mother and living with grandparents were also included in the study to determine what family structure affects youth incarceration. The study included various other factors such as the timing of the fathers' departure? How many disruptions did the family have? Instability of residence? Income? And lastly, whether lack of adult(s) in the household shows insufficient parenting. The researchers included these questions to their study in order to provide possible answers that they found were missing from previous research on incarceration. Life course theory allows 
researchers to look at transitions and turning points and how timing of turning points effects whether positive or negative bonds or attachment can affect the life trajectory.

The study found that youths living in a mother only, mother and step father household and youths that do not live with either their mother or father are three times more likely to face incarceration than youths that live in a dual household. Results show there was an increase in likelihood for youth incarceration in all family structures with residence instability. Youths that are living with their mother, mother and stepfather as well as living with relatives or others, had a significantly higher odds of incarceration. And as the researchers hypothesized youths that never had a father in the household had the highest odds of incarceration.

\section{$\underline{\text { Measures }}$}

Analysis - A tobit regression model was used because the dependent variable (delinquency) was clustered at zero. Linear regression models have values for all the variables in the sample but when there is left or right censoring in the dependent variable the tobit regression model estimates the linear relationships between variables. Respondents answered how many times they committed each delinquent act within twelve months in 1979. The responses ranged from zero to 60 times a delinquent act was committed. The dependent variable is left censored with an upper limit of 60 (total responses of delinquent acts committed by respondents in one year). The tobit model allows all responses for the dependent variable to be counted in the analysis, compared to other models such as ordinary least squares (OLS) which would discard respondents resulting in omitted variable bias due to a non-normative distribution.

Delinquency- My scale differed from Harpers (2004) in that it excludes forms of delinquency that do not yield financial gain (vandalism, violence, etc). I conceptualized 
delinquency as committing delinquent act(s) for monetary gain. For the purpose of this study I created an objective measure of delinquency from the 1980 survey. The delinquency scale included ten items that measure illegal activities for monetary gain: shoplifted in the past year, stolen items worth less than $\$ 50$, stolen items worth more than $\$ 50$, sold marijuana/hashish, sold hard drugs, stole a car, broken into a place, aided a gambling operation, knowingly sold/held stolen goods and attacked someone with intent to injure/kill them.

I then compiled a standardized summative scale using Stata. The scale revealed that the delinquency variable I created has a reliability coefficient (Cronbach's alpha) of 0.79 . Ideally one would like to have an alpha .80 or higher. Cronbach's alpha measures the reliability of the summative scale. "Cronbach's alpha will go up as you add more good items that measure the same underlying concept" (Cronbach, 1951) For instance in my study, delinquency is measured for monetary gain. Vandalism is defined by Clinard (1958) as "the deliberate defacement, mutilation or destruction of private or public property by a juvenile or group of juveniles not having immediate or direct ownership in the property abused". Clinard (1958) also argues that vandalism compared to other forms of juvenile property offenses has had a higher cost to the American public. Therefore, I removed vandalism as a delinquent act in my study when I recreated the delinquency scale from the Harper (2004) scale because conceptually it does not measure monetary gain. A summed category for criminal offending (delinquency) allows me to narrow the concept of criminal activity/behavior for monetary gain to be measurable.

Birth Order-The main independent variable in this study is the birth order of respondents, specifically if they are first born. I was able to create a birth order variable from the 1979 survey which asked, "if sibling is older than respondent?" I conceptualized that the "oldest" 
variable would include the respondent as an only child. An oldest variable was created using a dummy variable $1=$ oldest $(1,468)$ and only child $(203), 0=$ states that the respondent is not an only child or the eldest child (total number of siblings older than respondent 1-27). As shown on table 1 of 3,555 male respondents $23 \%$ or 1,671 are categorized as the "oldest" child.

Family Structure- In order to use family structure as an independent variable I created household variables from the 1979 survey for (1) a dual parent household,(2) single mother headed household and (3)single father headed household. A dual parent household includes the child living with both parents; this includes biological mother and father or a blended family (biological mother/father and step mother/father).

A separate variable (dad) was created using the question "does respondent live separately from (his/her) (father/stepfather)?” Out of 12,686 respondents 6,210 responded that they do not live separately from their father. 5,152 responded that they did live separately from their father and 1,185 were considered a valid skip on the original data. The valid skip was included in the total response to not living with father because it is implied through the questionnaire that 1,006 responded that their father was not living at the time and 179 responded that they did not know their father for a total of 6,337 of respondents living separately from their father.

Another variable was created (mom) using the question "does respondent live separately from (his/her) (mother/stepmother)?” Out of 12,686 respondents at total of 8,164 responded that they did not live separately from their mother. A total of 4,426 responded that they did live separately from their mother. The total is a combined response of 4,080 responding that they live separately from mother and a valid skip of 346 . The valid skip was also included to total response to living separately from mother because the previous question in the questionnaire 
asks "is you mother living at this time" 324 responded that their mother was not living and 22 responded "no" they did not know their mother. These questions imply that respondent was not living with mother/stepmother.

The NLSY79 included young adults up to age 22 that lived separately from parent(s) home and some had already started their own families. Respondents that were older than 18 years of age were dropped from the study $(n=4085)$ due to this study looking at adolescents committing delinquency for monetary gain in specific household structures. In order to get a dual parent effect, a new dummy $(1=$ yes, $0=$ no) dualparent variable was created. If the respondents answered yes they are living with "dad" and yes they are living with "mom" then they would be living in a dual parent household.

As such, I also created two other dummy variables (single parent female and male headed households). Respondents that answered "yes" to living with their mom/stepmother and "no" to living with father or stepfather were categorized as $1=$ yes they live in a single female headed household. If the respondents answered "no" to living with mom/stepmom or "no" to living with father/stepfather then they categorized as $0=$ not living in a single female headed household. Respondents that answered "yes" to living with father/stepfather and "no" to living with mother/stepmother were categorized as 1=yes they live in a single male headed household. The respondents that answered "no" to living with father/stepfather or "no" to living with mother/stepmother were categorized as $0=$ not living in a male headed household.

The results on table 1 are the total male respondents age 14-18 from the survey in household structures. Results show that of 3,606 respondents $64 \%$ of male respondents were living in a dual parent household during 1979 . There are a total $22 \%$ of male respondents living 
in a single parent female (mom) headed household. And a total of 3\% of male respondents lived in a single parent male (dad) headed household.

Common background- Variables for race was included in the model that includes white, black and other. Urban residences as well as region of residence are included as control factors for delinquency. By adding the regional and urban variable it allows me to test whether the propensity of delinquency is increased or decreased based on the region one lives in and whether living in a rural or urban setting increases or decreases delinquency. Control factors for region included northeast, northcentral, west and south. I used the West region as the reference category for the region because the Harper (2004) article had also included all regions. Harper's (2004) study found that the West region had higher odds likelihood for youth incarceration with father absenteeism. Poverty was also included as a control factor because "youth in poverty are more often raised by a single parent" (Bersani, 2007). Poverty can also affect single parent households but especially single female headed households that need extra resources since there is only one adult to care for the children. 
Table 1. Mean, Standard Deviation, Minimum, Maximum and Numbers for Dependent and Independent Variables holding males constant

Mean $\begin{gathered}\text { Standard } \\ \text { Deviation }\end{gathered} \quad$ Minimum Maximum $\quad N$

\begin{tabular}{|c|c|c|c|c|c|}
\hline \multicolumn{6}{|l|}{ Dependent Variable } \\
\hline Delinquency & 3.36 & 6.036 & 0 & 60 & 3342 \\
\hline \multicolumn{6}{|l|}{ Independent } \\
\hline Variable & & & & & \\
\hline (1)Oldest & 0.236 & 0.425 & 0 & 1 & 3555 \\
\hline (2)Dualparent & 0.643 & 0.479 & 0 & 1 & 3606 \\
\hline Singleparent-female & 0.224 & 0.417 & 0 & 1 & 3625 \\
\hline Singleparent-male & 0.033 & 0.181 & 0 & 1 & 3641 \\
\hline \multicolumn{6}{|l|}{ Control Variables } \\
\hline White & 0.554 & 0.497 & 0 & 1 & 3669 \\
\hline Black & 0.273 & 0.445 & 0 & 1 & 3669 \\
\hline Other & 0.173 & 0.378 & 0 & 1 & 3669 \\
\hline Urban & 0.776 & 0.417 & 0 & 1 & 3607 \\
\hline NorthEast & 0.202 & 0.402 & 0 & 1 & 3612 \\
\hline NorthCentral & 0.258 & 0.437 & 0 & 1 & 3612 \\
\hline West & 0.181 & 0.385 & 0 & 1 & 3612 \\
\hline South & 0.359 & 0.478 & 0 & 1 & 3612 \\
\hline Poverty & 15992.98 & 12659.68 & 0 & 75001 & 3011 \\
\hline
\end{tabular}

Source: National Longitudinal Survey of Youth 1979

Note: age range respondents for the NLSY79 is 14-22years of age. For this study we limit the respondents to age 14-18 years of age.

\section{Results}


The first research question asks if delinquent acts for monetary gain increase if a juvenile is a first born male. The result in table 2 regression model (1) show there is no statistical significance with the result of a .38 unit decrease in committing delinquent acts if the juvenile male is the oldest child. The results suggest that oldest juvenile males commit less delinquency. The second research question asks if delinquent acts for monetary gain increases if the juvenile is a first born male and living in a single female headed household. The results in table 2 regression model (2) does not support that there is an increase in delinquent acts for monetary gain living in single female headed households compared to oldest males living in a dual parent .

Other Findings- The second regression model in table 2 shows that there is statistical significance at $\mathrm{p}<0.05$ level for single male headed households where delinquent acts in oldest juvenile males are increased by 1.47 times than an oldest juvenile male living in a dual headed household. This result was unexpected but I have to look at possible explanations. When looking at single male headed households there is a possibility that men tend to have longer work hours than women and therefore are at home less to supervise children at home. Another explanation as to the effect of why single male headed households have a higher likelihood for adolescent males to commit more delinquent acts may be that men are less nurturing than women so this may create a separation of bond between father and child compared to the mother or mother figure. A decrease in delinquent acts by oldest males living in a single female headed household may be attributed to the positive bond with the mother therefore reinforcing Hirschi's (1969) bond theory. Further research is recommended in order to test both hypotheses.

The results in the third tobit regression model in table 2 show that there is statistically significant decrease in delinquent acts by oldest black males by .81 units $(\mathrm{p}<0.01)$ than oldest 
males that are white. There is also a decrease in delinquent acts committed by the "other" race by 1.35 units $(\mathrm{p}<0.001)$ holding the race "white" constant. The results differed in the Harper (2004) study which tested whites, blacks and Hispanics in their common background factors and low income hypotheses compared to this study. The results show that whites have a lower likelihood to be incarcerated due to father absence than blacks and Hispanics. Harper (2004) did include additional caregivers in their model to see whether assistance from grandparents would lower the odds of incarceration. The study found that grandparents had a close to significant $(\mathrm{p}=0.052)$ positive effect on youths odds of incarceration but, they did not include race. Thomas et al (1996) discusses differences in single parent households between whites and blacks. The study states that, "African-American grandparents and extended families are more likely to provide support to single mothers" (page 885). Having extended families as a support system for the single parent especially a female and the adolescent can be attributed to positive bonds and how an individual can be deterred from criminal behavior.

Fomby (2013) also found that "White adolescents are more likely than black adolescents to make a long-distance move following a family structure transition [as such] black adolescents may be more likely to remain in the same geographic area following a family structure change.... and that black adolescents in unstable families were more likely than similar white adolescents to maintain social ties to extended kin, neighbors and other adults" (page188). Thomas et al (1996) found that white males reported more delinquency when living in a single mother family with no father involvement and black males reported less delinquency when living in a single mother family with no father involvement. The negative or lack of bond with a father caused by divorce or separation can also explain the onset of criminal behavior. 
Consistent with the Harper (2004) study, results in the tobit regression model three in table 2 show that the control factors for living in an urban setting increases by .86 units $(\mathrm{p}<0.01)$ for committing delinquent acts compared to living in a rural setting. Urban cities tend to have higher population, high poverty level and higher crime rates than rural areas. Lastly, the results in the third tobit regression model on table 2 shows a decrease of $1.13(\mathrm{p}<0.01)$ delinquent acts committed by males that live in the north central region holding the west region constant. There is also a decrease of $1.81(\mathrm{p}<0.001)$ delinquent acts committed by males that live in the southern region holding the west region constant. Again, the results are consistent with Harper's (2004) study in which she states that "father absence and crime rates are higher in metropolitan areas and in the West and South (page 348)". Harper's (2004) results show that the West region had a higher probability for youth incarceration due to father's absence.

\section{Section V}

Discussion- A unique opportunity in an undergraduate class allowed me to have discussions with incarcerated men about their onset to criminal behavior. From those conversations, I noticed a pattern: most of the men I spoke with are first born males that lived in single female headed households; they did not have a relationship with their father due to divorce, incarceration or death and had younger siblings. The men discussed the burden they felt because of being the eldest child and how they were referred to as the "man of the house". As a young adolescent the men could not provide financial support through legitimate work so instead they resorted to committing delinquent acts in order to assist with food and money through stealing and/or selling drugs, along with other delinquent acts that they would view as a benefit to themselves and the family. 
Because of the discussions I had with the men, I wanted to test whether: (1) first born males living in a single parent headed household are more likely to commit delinquent acts for monetary gain? And (2) are first born males living in a single female headed household more likely to commit delinquent acts for monetary gain? The results on table 3 suggests there is no relationship in (1) first born males living in a single parent headed household are less likely to commit delinquent acts for monetary gain and (2) first born males living in a single female headed household are less likely to commit delinquent acts for monetary gain.

Looking back at some possible explanations as to why the results did not support my research questions, I have to consider that there are discrepancies in the variables. I had made the argument that previous studies that look at birth order argue that only children can be classified as the oldest, as well as the youngest child and in some instances completely removed from the study sample. When I created the 'oldest' variable in birth order, I included respondents that are only children in order to maximize the cases for analysis. The study by Warren (1996) found that the only child was more like the youngest child than the oldest, and that the middle and youngest children are more prone to delinquency than first born children.

The total 'oldest' child in my study was 1,671 or $23 \%$ of the total male respondents $(3,555)$, I re-ran the model taking the only children $(n=203)$ out of the model to see if that would change my results. The results showed there is no measurable difference by excluding the only children from the model. I also re-ran the model to see if the second or youngest child was more likely to commit delinquent acts but there was no measurable difference from my original model that tested first born males including the only child. When I reran the model I used the delinquency scale for monetary gain but, I was not making an argument for second born children to commit delinquent acts for monetary gain. Studies have shown that delinquents come from larger 
families (West, 1973 and Rahav, 1980) changing the delinquency scale that was measured for monetary gain to other forms of delinquency such as marijuana use and truancy could have given me different results.

The delinquency scale that was constructed by the Harper (2004) study included eleven items that measure illegal activities. For the purpose of my study I used ten of the eleven items that Harper included in her study. Since I was looking the man of the house role and how a sense of responsibility was placed on the incarcerated men as children, I conceptualized delinquency to be acts of delinquency for monetary gain. When measuring delinquency other studies have divided delinquency into categories such as; status offenses (truancy and running away), use of drugs, property crimes, violence and contact with the criminal justice system. Depending on what type of delinquent act is being measured will determine which delinquent response will be included in the delinquency scales. The argument can also be made that an individual may not be committing delinquency to help their family but instead are committing delinquent acts for financial independence. The delinquency variable was an objective measure that I had constructed; as such it has not been used in other studies. Further research is needed for the delinquency scale that was constructed for the purpose of monetary gain.

Vespa (2013) reported that data from the 2012 Census showed that "father only households were in better economic standing compared to mother only households" (page 13). Mother only households were four times more likely to live below the poverty and receive food stamps as compared to the nine percent of dual families living below the poverty line and receiving food stamps. It was reported that father-only groups have higher rates of employment, better educational background and a lower rate of food stamps as compared to mother only groups. The oral retrospectives from the incarcerated men has relevance in the data presented from the 
Census report in 2012 (Vespa, 2013), but this study suggests that there is no correlation between birth order, delinquency for monetary gain and household structure.

Participation in the Inside-Out class was a unique experience for both the inside and outside students because it was the first class offered at the correctional facility. The facility where the class was held was inside a men's maximum security facility. Both the inside and outside students were hand-picked by either the professor or the facility administration due to the level of security in the facility. The weekly readings allowed the men to reflect on the criminological theories as they were introduced in the class; as such the discussions that occurred during class were influenced by the weekly readings. The population within the facility cannot be generalized the rest of the incarcerated population due to the nature of their criminal conviction (drug related charges, violent offenses) and length of sentence (men serving up to life sentences). Only one percent of the population in the facility was selected into the class. There may be a sub-set within individuals that are incarcerated that further research is needed in order to capture the onset to criminal behavior as the incarcerated men had suggested. Further research is also recommended on the selection process for both inside and outside students within different facilities that can determine if the class is influential in desistence and possible persistence of criminal behavior.

Sampson and Laub (2003) stated that "offenders [labeled "super predators", "chronic offenders", "career criminals" and "life-course persisters" are used frequently in the criminological literature] represent challenges for both criminological theory and criminal justice policy, yet it is remarkable how little we know about them" (page 18). Ideally a better data set such as a longitudinal study that captures the life-course (transitions, trajectories and turning points) of incarcerated individuals could show an understanding of the subset population within incarcerated individuals. 
A limitation to my study is that I looked at a moment in the adolescents' life instead of looking at sequences in time like life course theory suggests. As such, the study did not capture the turning point(s) caused by the transitions. A qualitative study could better capture the "man of the house' role that the incarcerated men had described during class discussions. Further research is needed on the implications that being labeled the "man of the house" can have. The label does not have to have a negative effect; it could also have positive effects on individuals that have lived or live in similar situations.

A qualitative study can also focus on open-ended questions that can capture family transitions that may have been missed in a questionnaire such as questions on cohabitation in which Mitchell (2013) suggests that looking at changes in relationships with parents and their new partners as well as how often these changes occur could have an effect on the child. Conducting a qualitative study in urban areas that have a higher crime rates could find a correlation between father absence, female headed households and onset criminal behavior of the oldest child. Although the study would not be able to be generalized to the eldest child population or to children that live in female headed households it can look into the idea of personal responsibility for being labeled the "man of the house." 
Table 2

Estimates of tobit regression model of birth order to delinquency for monetary gain holding male constant

\begin{tabular}{|c|c|c|c|}
\hline Regression Model & (1) & (2) & (3) \\
\hline Oldest & -0.38 & -0.35 & -.32 \\
\hline \multicolumn{4}{|l|}{ Household } \\
\hline Dualparent $^{\mathrm{a}}$ & & - & - \\
\hline $\begin{array}{l}\text { Singleparent- } \\
\text { female }\end{array}$ & & 0.42 & 0.45 \\
\hline Singleparent-male & & $1.47 *$ & 1.21 \\
\hline \multicolumn{4}{|l|}{$\underline{\text { Race }}$} \\
\hline White $^{\mathrm{b}}$ & & - & - \\
\hline Black & & & $-0.81 * *$ \\
\hline Other & & & $-1.35^{* * *}$ \\
\hline Urban & & & $0.86^{* *}$ \\
\hline \multicolumn{4}{|l|}{$\underline{\text { Region }}$} \\
\hline West $^{c}$ & & & - \\
\hline Northeast & & & -0.76 \\
\hline Northcentral & & & $-1.13 * *$ \\
\hline South & & & $-1.81 * * *$ \\
\hline Poverty & & & -0.00001 \\
\hline
\end{tabular}

Source: National Longitudinal Survey of Youth 1979

$\mathrm{N}=2532$

${ }^{a}$ Reference category for household structure is Dualparent

${ }^{\mathrm{b}}$ Reference category for race is White

${ }^{\mathrm{c}}$ Reference category for region is West

$* \mathrm{p}<0.05, * * \mathrm{p}<0.01, * * * \mathrm{p}<0.001$ 


\section{Bibliography}

Antecol, H. and Bedard, K. (2007). "Does Single Parenthood Increase the Probability of Teenage Promiscuity, Substance Use, and Crime?" Journal of Population Economics. Vol. 20 No. 1 pp. $55-71$

Bersani, B. and Chappie, C. (2007). "School Failure as an Adolescent Turning Point". Sociological Focus Vol. 40, Issue 4, 2007 pp. 370-391

Clinard, M. and Wade, A. (1958) "Toward the Delineation of Vandalism as a Sub-Type in Juvenile Delinquency". The Journal of Criminal Law, Criminology, and Police Science, Vol. 48, No. 5 (Jan-Feb., 1958), pp 493-499

Cronbach, L. (1951). "Coefficient Alpha and the Internal Structure of Tests". Psychometrika, Volume 16 Issue 3, pp. 197-334

Cundiff, P. (2013). Ordered Delinquency: The "Effects" of Birth Order on Delinquency. Personality and Social Psychology Bulletin. Vol. 39 no. 8 page 1017-1029

Elder, G. (1985). "Perspectives on the Life Course". Life Course Dynamics: Trajectories and Transitions, 1968-1980, edited by Elder, G. Cornell University Press

Fomby, P. and Sennott, C. (2013) "Family structure instability and mobility: The consequences for adolescents problem behavior". Social Science Research. Vol. 42 pp.186-201 Fund

Glueck, S., Glueck, E. (1950) Unraveling Juvenile Delinquency. New York. Commonwealth

Harper, C. , McLanahan, S.(2004). "Father Absence and Youth Incarceration”. Journal of Research on Adolescence, 14(3) pp. 369-397

Hirshi, T. (1969). Causes of Delinquency. Berkely: University of California Press

Johnson, M., Mollborn, S. (2009). Growing up Faster, Feeling Older: Hardships in Childhood and Adolescence. Social Psychology Quarterly, Volume 72, NO. 1 pp.39-60

Langenkamp, A. and Frisco, M. (2004). "Family Transition and Adolescent Severe Emotional Distress: The Salience of Family Context”. Social Problems, Vol. 55 No. 2 pp. 238253

Laub, J. and Sampson, R. (2003). Shared Beginnings, Divergent Lives: Delinquent Boys to Age 70. Cambridge, MA: Harvard University Press

Mitchell, K. (2013). "Pathways of children's long-term living arrangements: A latent class analysis”. Social Science Research”, Volume 42, pp.1284-1296 
Rahav, G. (1980) "Birth Order and Delinquency". The British Journal of Criminology.. Volume 20 pp. 385-395

Rowe, C., Rodgers, J., Meseck-Bushey, S. (1992). "Sibling Delinquency and the Family Environment: Shared and Unshared Influences". Child Development, Volume 63, No. 1, pp. 5967

Sampson, R. and Laub, J. (1993). Crime in the Making: Pathways and Turning Points Through Life. Cambridge, MA: Harvard University Press

Shaw, C. and McKay, H. (1942). Juvenile Delinquency and Urban Areas. Chicago: University of Chicago Press

Sutherland, E. (1939). Principles of Criminology. Lippincott, Philadelphia.

Sweeten, G. (2011) "Scaling Criminal Offending'”. Journal of Quantitative Criminology, Volume 28, Issue 3, pp 533-557

Thomas, G., Farrell, M. and Barnes, G. (1996). "The Effects of Single-Mother families and Nonresident Fathers on Delinquency and Substance Abuse in Black and White Adolescents". Journal of Marriage and Family, Vol. 58 No. 4 pp.884-894

Uggen, C. (2000). "Work as a Turning Point in the Life Course of Criminals: A Duration Model of Age, Employment, and Recidivism". American Sociological Review, Volume 67, pp. 529-546

Vespa, J., Lewis, J., and Kreider, R. (2013). America's Families and Living Arrangements: 2012, Current Population Reports, P20-570, U.S. Census Bureau, Washington, DC. 49.

Warren, J. (1966) "Birth Order And Social Behavior". Psychological Bulletin 65.1, pp.38- 